\title{
Foliar application of entomopathogenic nematodes (Rhabditida: Steinernematidae and Heterorhabditidae) for the control of Diatraea saccharalis in greenhouse
}

\section{Aplicação foliar de nematóides entomopatogênicos \\ (Rhabditida: Steinernematidae e Heterorhabditidae) para o controle de Diatraea saccharalis em casa de vegetação}

\author{
Luiz Luciano Bellini ${ }^{1}$; Claudia Dolinski2 ${ }^{*}$
}

\begin{abstract}
The sugarcane borer, Diatraea saccharalis, makes tunnels in the cane stalk, causing weight loss, as well as bud death, impairing germination. The weakened stalks are also more prone to breakage by wind, and in young plants the inner whorl of the leaves can die, resulting in a condition known as "dead heart". Chemical control is used, but with low efficiency. This work was designed to test biological control of $D$. saccharalis using entomopathogenic nematodes (NEPs). Two trials in the greenhouse were performed using Heterohabditis baujard LPP7 and Steinernema carpocapse NCAll by foliar application associated with adjuvants. In the first assay, the number of holes per stalk was 3.4 for the control without nematodes and with Joint* Oil; 3.14 for the control without nematodes and with Gotafix ${ }^{\circledR ;} 2.44$ for $S$. carpocapsae NCAll + Joint* Oil; 2.06 for H. baujardi LPP7 + Gotafix ${ }^{\circledR}$ and also for S. carpocapsae NCAll + Gotafix ${ }^{\circledR}$; and 1.84 for H. baujardi LPP7 + Joint* Oil. In the second assay, the treatments showed an average of 4.78 holes per stalk for the control without nematodes and with Gotafix ${ }^{\circledR} ; 4.76$ for the control without nematodes and with Joint* Oil; 2.18 for $S$. carpocapsae NCAll + Joint* Oil and for $S$. carpocapsae NCAll + Gotafix ${ }^{\circledR} ; 1.96$ for H. baujardi LPP7 + Gotafix ${ }^{\circledR}$; and 1.90 for H. baujardi LPP7 + Joint* Oil. In the two experiments, the treatments with and without the EPNs differed significantly, but there was no difference between the adjuvants or between the two EPN species.
\end{abstract}

Key words: Biological control, sugarcane borer, NEPs, Saccharum officinarum

\section{Resumo}

\begin{abstract}
A broca-da-cana, Diatraea saccharalis, causa danos à cana-de-açúcar devido ao seu hábito de formar galerias nos colmos, o que acarreta em perda do peso do produto, redução da sacarose e a seca dos ponteiros. O controle químico é utilizado, porém, com baixa eficiência, pois a larva permanece maior parte do tempo de seu desenvolvimento dentro dos colmos. Este trabalho teve como objetivo testar o controle biológico da $D$. saccharalis, utilizando-se nematóides entomopatogênicos (NEPs). Para tanto, foram realizados dois ensaios em casa de vegetação utilizando-se Heterohabditis baujardi LPP7 e Steinernema carpocapse NcAll por pulverização foliar, associados a produtos adjuvantes. No primeiro ensaio, o número médio de furos causados pela broca-da-cana, nas testemunhas Joint* Oil e Gotafix ${ }^{\circledR}$ foram de 3,4 e 3,14 respectivamente. Já quanto aos tratamentos, o número de furos por colmo analisado foi de 2,44 para $S$. carpocapsae NCAll + Joint* Oil; 2,06 para H. baujardi LPP7 + Gotafix ${ }^{\circledR} ; 2,06$ para S. carpocapsae NCAll + Gotafix ${ }^{\circledR}$; e 1,84 para H. baujardi LPP7 + Joint* Oil. Quando o experimento
\end{abstract}

\footnotetext{
${ }^{1}$ Discente, Universidade Estadual do Norte Fluminense Darcy Ribeiro, UENF. Campos dos Goytacazes, Rio de Janeiro, RJ. E-mail:1lbufv@hotmail.com

${ }^{2}$ Prof ${ }^{a}$. da UENF, Campos dos Goytacazes, Rio de Janeiro, RJ. E-mail: claudia.dolinski@censanet.com.br

${ }^{*}$ Author for corespondence
} 
foi repetido, o número médio de furos nas testemunhas Gotafix ${ }^{\circledR}$ e Joint* Oil, foram respectivamente 4,78 e 4,76. Quanto aos tratamentos $S$. carpocapsae NCAll + Joint* Oil, S. carpocapsae NCAll + Gotafix ${ }^{\circledR}$, H. baujardi LPP7 + Gotafix ${ }^{\circledR}$ e H. baujardi LPP7 + Joint* Oil, apresentaram o número médio de 2,18; 2,18; 1,96 e 1,96 furos por colmos avaliados. Assim, ambos nematóides controlaram a broca da cana, contudo não houve diferença significativa entre NEPs e produtos adjuvantes.

Palavras-chave: Controle biológico, broca-da-cana, NEPs, Saccharum officinarum

\section{Introduction}

The Brazilian sugarcane harvest for 2010-2011 amounted to 624.99 million tonnes (metric tons). Of this quantity, $53.8 \%$ (336.2 million tonnes) was used to produce 27.7 billion liters of ethanol and $46.2 \%$ (288.7 million tonnes) was used to make sugar (CONAB, 2011). These figures make Brazil among the world leaders in both products. Brazil has been a leading producer of sugar since colonial times, while the importance of ethanol production dates only from the late 1970s, and is becoming more important because of the efforts of many countries to reduce their reliance on petroleum as a fuel source (MOZAMBANI et al., 2006). However, as all crops, sugarcane is subject to attack by pests during its growing cycle, reducing its quality and productivity. These problems are becoming worse as the area planted with cane increases (MACEDO; MACEDO, 2007).

The main sugarcane pest in Brazil is the sugarcane borer, Diatraea saccharalis (Fabricius) (Lepidoptera: Crambidae), due to its wide distribution and the damage it causes (GALLO et al., 1988; LIMA FILHO, 1999). The larvae of this moth bore tunnels in the cane stalk, causing weight loss, as well as bud death, impairing germination. The weakened stalks are also more prone to breakage by wind and in young plants the inner whorl of the leaves can die, resulting in a condition known as "dead heart" (GALLO et al., 2002). Each 1\% of intensity of infestation by this pest causes weight loss of $0.77 \%$, resulting in losses of $0.25 \%$ in sugar output or $0.20 \%$ in ethanol yield (GALLO et al., 2002; CAMPOS; MACEDO, 2004).

The use of larvae of the endoparasitoid wasp Cotesia flavipes (Cameron) (Hymenoptera:
Braconidae) to control the sugarcane borer has been shown to be efficient (ALMEIDA; STINGEL, 2005 ) and is the most widely used method in Brazil (PINTO; GARCIA; OLIVEIRA, 2006). The success in using this species to control the cane borer has led to investments by laboratories in more efficient and profitable mass breeding methods (CARVALHO, 2006).

Chemical control is also employed, but it is not very efficient because the borers remain inside the stalks, protected from contact with the pesticide (PINTO; GARCIA; OLIVEIRA, 2006). The use of entomopathogenic nematodes (EPNs) (Rhabditida: Steinernematidae and Heterorhabditidae) has been successful in many countries to control various crop pests, especially those that traverse the soil or inhabit cryptic environments (LEITE et al., 2006, DOLINSKI; VALLE; STUART, 2006). EPNs of the Steinernema and Heterorhabditis genera live in the soil and are natural parasites of insects found in this ecosystem, as well as having a symbiotic relationship with bacteria of the Xenorhabdus and Photorhabdus genera, respectively (FORST; CLARKE, 2002).

Entomopathogenic nematodes have already been tested against other sugarcane pests. Two studies by Spaull $(1988,1990)$ in Africa showed that the EPNs Heterorhabditis and Steinernema can reduce the population of Eldana saccharina Walker (Lepidoptera: Pyralidae) on sugarcane. Also in Africa, Pillay et al. (2009) obtained 100\% mortality of E. saccharina by using isolates of these two EPN genera 48 hours after treatment.

In the United States and Japan, billbugs of the Sphenophorus genus have been efficiently controlled by the use of $H$. bacteriophora Poinar 
and $S$. carpocapsae (Weiser) Wouts, Mracek, Gerdin \& Bedding (SMITH, 1994; SHAPIROILAN; GOUGE; KOPPENHÖFER, 2002).

In Brazil, Leite et al. (2002) obtained 80\% mortality of the sugarcane spittlebug, Mahanarva fimbriolata (Fabr.) (Hemiptera: Cercopidae) by applying Heterorhabditis sp. and Steinernema sp. nematodes. In turn, Tavares et al. (2007) applied 60 infective juveniles (IJs) per $\mathrm{cm}^{2}$ of $H$. indica Poinar, Karunakar \& David IBCB-n5 against Sphenophorus levis (Coleoptera: Curculionidae) and obtained mortality of $95 \%$ in the laboratory and $85 \%$ in the greenhouse. When they used Steinernema sp. IBCB-n6, the rates were $73 \%$ in the laboratory and $42 \%$ in the greenhouse.

The entomopathogenic nematodes Steinernema glaseri (Steiner) Santa Rosa and H. indica IBCB-n5 were tested against eggs and larvae of Migdolus fryanus Westwood (Coleoptera: Cerambycidae) in laboratory experiments. There was no significant difference between the treatments. However, in both cases there was penetration by the nematode and reduction of the viability of the infected eggs. Regarding the $M$. fryanus larvae, S. glaseri caused $100 \%$ mortality and $H$. indica caused $80 \%$, in both cases significantly different from the control (MACHADO et al., 2005).

For leaf application, the most commonly applied species is $S$. carpocapse NCall (BAUR; KAYA; TABASHNIK, 1997; BAUR; KAYA; THURSTON, 1995; PEREZ, et al., 2000). However, there are no reports in the literature on the leaf application of $H$. baujardi LPP7. Therefore, the aim of this study was to test a new alternative for control of $D$. saccharalis in sugarcane, by comparing the application of the entomopathogenic nematodes $S$. carpocapse NCall and $H$. baujardi LPP7 by leaf spraying, with and without adjuvants, in a greenhouse experiment.

\section{Material and Methods}

The experiments were performed at the Entomology and Phytopathology Laboratory of
Universidade Estadual do Norte Fluminense Darcy Ribeiro (state of Rio de Janeiro, Brazil) and in a greenhouse on the campus.

The two EPN species, H. baujardi Phan et al. LPP7 and S. carpocapae (Weiser) NCAll, were multiplied in larvae of the last instar of Galleria mellonella (L.) (Lepidoptera: Pyralidae) in a breeding group maintained by the laboratory. These larvae were infested in Petri dishes ( $9 \mathrm{~cm}$ diameter) lined with two sheets of filter paper moistened with $2 \mathrm{~mL}$ of a nematode suspension containing approximately 200 IJs. The dishes were sealed with plastic film, identified and placed in a BOD chamber at $25 \pm 1^{\circ} \mathrm{C}$ and $\mathrm{RH}>80 \%$ for 48 hours. The dead larvae were transferred to modified White traps (WHITE, 1927). These traps were made of Petri dishes $(9 \mathrm{~cm}$ in diameter) with a PVC ring $(3 \mathrm{~cm}$ diameter $\mathrm{x} 1 \mathrm{~cm}$ height), with a sheet of filter paper placed over the ring $(2 \mathrm{~cm} \mathrm{x} 4 \mathrm{~cm})$. The dead larvae were placed over the paper and distilled water was added in the base of the dish until reaching half way up the PVC ring. The traps were then placed in the BOD chamber $\left(25 \pm 1{ }^{\circ} \mathrm{C}\right.$ and $\left.\mathrm{RH}>80 \%\right)$ until emergence of the IJs. These were collected with Pasteur pipettes every other day for 12 days, placed in cell culture bottles $(1,000 \mathrm{~mL})$, identified regarding collection date and stored in a climatecontrolled chamber at $16 \pm 1{ }^{\circ} \mathrm{C}$ and $\mathrm{RH}>80 \%$ for no more than one week before the experiments, so that the juveniles would not lose their infectiveness.

The D. saccharalis specimens and sugarcane setts (stalk sections) were donated by Universidade Federal Rural do Rio de Janeiro campus Dr. Leonel Miranda (UFRRJ) in Campos dos Goytacazes, RJ

The experimental design was fully randomized blocks, with six treatments and ten repetitions. Besides the IJs of $H$. baujardi LPP7 and $S$. carpocapae NCAll, two chemical adjuvants were also tested, Joint* Oil (Dow AgroSciences) and Gotafix ${ }^{\circledR}$ (Milenia) (Table 1). Two experiments were performed, one after the other, with the same treatments, to confirm the results. 
The experiments were conducted with six 20-liter pots, each planted with five sugarcane setts (variety RB 72454). To determine the volume of solution to be applied in each treatment, initial tests were performed using a sprayer with $5 \mathrm{~L}$ capacity. Four months after planting, two D. saccharalis caterpillars, 12 days old, were placed on each of three axils per stalk, for a total of six caterpillars per stalk and 30 per pot. After 48 hours, each pot was sprayed with $1 \mathrm{~L}$ of the respective treatment solution (Table 1).
The evaluation of the mortality of the $D$. saccharalis larvae was carried out one week after application of the EPNs. All the stalks were cut at soil level and then lengthwise. In each treatment the dead larvae were collected and placed in White traps, to prove the efficiency of the EPNs.

The data on the dead larvae for each stalk were submitted to analysis of variance and the means were compared by the Tukey test $(\mathrm{P}=0.05)$.

Table 1. Treatments used in each assay under greenhouse conditions.

\begin{tabular}{|c|c|c|c|c|c|c|}
\hline & \multicolumn{6}{|c|}{ Treatments } \\
\hline Constituents & $\mathrm{A}$ & $\mathrm{B}$ & $\mathrm{C}$ & $\mathrm{D}$ & $\mathrm{E}$ & $\mathrm{F}$ \\
\hline $\begin{array}{l}\text { Number of infective juveniles } \\
\text { of } H \text {. baujardi LPP7 }\end{array}$ & - & - & 500.000 & 500.000 & - & - \\
\hline $\begin{array}{l}\text { Number of infective juveniles of } S \text {. } \\
\text { carpocapsae All }\end{array}$ & - & - & - & - & 500.000 & 500.000 \\
\hline Joint* Oil & $\begin{array}{r}50 \\
\mathrm{~mL}\end{array}$ & - & $50 \mathrm{~mL}$ & - & $50 \mathrm{~mL}$ & - \\
\hline Gotafix ${ }^{\circledR}$ & - & $5 \mathrm{~mL}$ & - & $5 \mathrm{~mL}$ & - & $5 \mathrm{~mL}$ \\
\hline
\end{tabular}

Source: Elaboration of the authors.

\section{Results and Discussion}

In the two experiments, the treatments with and without the EPNs differed significantly, but there was no difference between the adjuvants or between the two EPN species.

In the first assay, the number of holes per stalk was 3.4 for the control without nematodes and with Joint* Oil; 3.14 for the control without nematodes and with Gotafix ${ }^{\circledR} ; 2.44$ for $S$. carpocapsae NCAll + Joint* Oil; 2.06 for H. baujardi LPP7 + Gotafix ${ }^{\circledR}$ and also for $S$. carpocapsae NCAll + Gotafix ${ }^{\circledR}$; and 1.84 for H. baujardi LPP7 + Joint* Oil $(\mathrm{P}<0.01$; gl $=5 ; \mathrm{F}=6.2858$ ) (Figure 1A). In the second assay, the treatments showed an average of 4.78 holes per stalk for the control without nematodes and with Gotafix ${ }^{\circledR} ; 4.76$ for the control without nematodes and with Joint* Oil; 2.18 for S. carpocapsae NCAll + Joint* Oil and for S. carpocapsae NCAll + Gotafix ${ }^{\circledR}$; 1.96 for H. baujardi LPP7 + Gotafix ${ }^{\circledR}$; and 1.90 for H. baujardi LPP7 + Joint* Oil $(\mathrm{P}<0.01$; $\mathrm{gl}=5 ; \mathrm{F}=183.0643$ ) (Figure 1B).

In the treatments with application of EPNs, the number of holes was lower than in the treatments without application of the EPNs. The suspension of EPNs sprayed on the plants ran from the leaves to the inside of the stalk via the leaf sheaths, possibly carrying the nematodes, which reached the larvae inside the stalk. Proof that the death of the larvae found in the leaf sheath regions and inside the stalk of the treated plants was caused by the EPNs was achieved by obtaining IJs from the dead caterpillars, placed in the modified White traps.

There was no difference in the level of control provided by the two species tested, even though they have different foraging strategies. H. baujardi is attracted by the cues given off by the target host, such as carbon dioxide, actively searching for the host in a "cruiser" strategy. In contrast, $S$. carpocapsae 
has an "ambusher" strategy, whereby it senses the approach of a host and jumps, without directional response, trying to penetrate the host's cuticle when successfully landing on one (ISHIBASHI, 2002; LEWIS, 2002). Lewis (2002) reported that cruiser EPNs are more effective against insects with low motility in the soil while ambushers are more effective against motile targets. However, in this work there were no significant differences between the species, because the form of moving from the leaf to the host was the same. The architecture of the sugarcane leaf and sheath, in the shape of a trough, favors the flow of the aqueous solution containing the EPNs in suspension to the inside the stalk. Therefore, the anatomical characteristic of this plant probably provided the same opportunity for both nematode species to find the holes bored by the host.

Figure 1 A-B. Two bioassays showing number of holes caused by the sugar borer, Diatraea saccharalis, in sugarcane setts in different treatments under greenhouse conditions. Means with the same letter are not statistically different by Tukey's test $(\mathrm{P}<0.05)$. LPP7: Heterorhbaditis baujardi LPP7; NCAll: Steinernema carpocapsae NCAll. Joint oil and Gota mix: adjuvants.

A

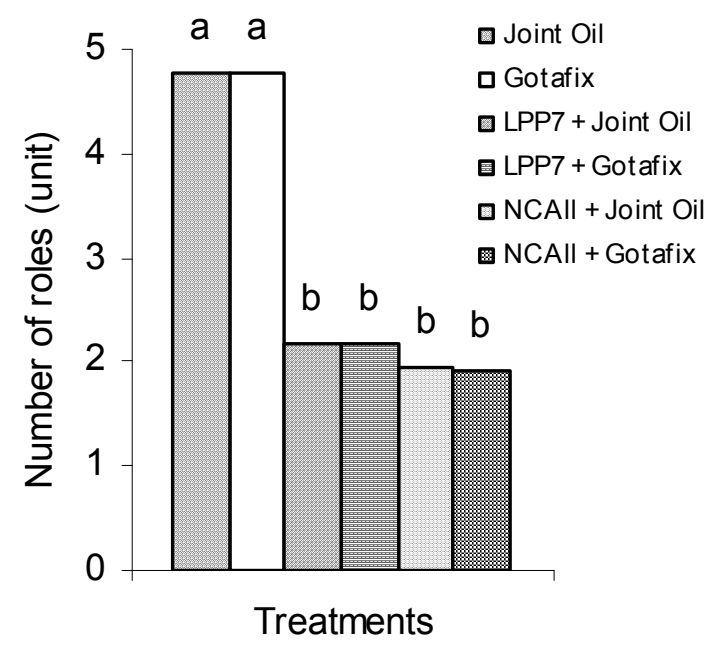

Source: Elaboration of the authors.

There also was no significant difference between the two adjuvants used. Silva, Silva and Voss (2008) also used the adjuvant Gotafix ${ }^{\circledR}$ in experiments with EPNs, observing that it provided greater survival of Heterorhabditis sp. isolate EPNET 19 (Nematoda: Heterorhabditidae). The use of entomopathogenic nematodes to control agricultural pests is now a reality due to their active capacity to find and control the target pests. Since the two nematodes, with the two adjuvants, applied in a semi-controlled situation,
B

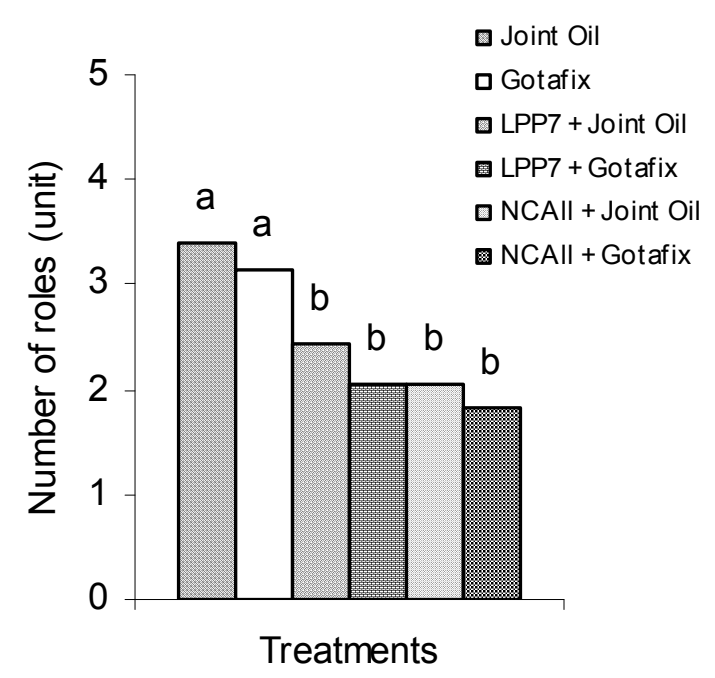

reduced the damages caused by $D$. saccharalis in sugarcane stalks, we recommend combining $H$. baujardi LPP7 with Joint Oil*. Besides having an active cruiser foraging strategy, with the ability to seek out the host in the stalk, this nematode is native to Brazil (DOLINSKI et al., 2008).

Based on the results obtained in the present study, it can be concluded that the EPNs tested have potential for use in the biological control of D. saccharalis in sugarcane plantations. However, 
further research is necessary about the technical and economic feasibility of using this natural enemy of the sugarcane borer in field conditions.

\section{Acknowledgments}

We acknowledge funding from UENF and CNPq (National Council for Scientific and Technological Research) and the Department of Entomology of Universidade Federal Rural do Rio de Janeiro campus Dr. Leonel Miranda, for donating the material for the experiments.

\section{References}

ALMEIDA, L. C.; STINGEL, E. Curso de monitoramento e controle de pragas da cana-de-açúcar. Piracicaba: Centro de Tecnologia Canavieira, 2005. 32 p.

BAUR, M. E.; KAYA, H. K.; TABASHNIK, B. E. Efficacy of a dehydrated Steinernematid nematodes against black cutworm (Lepidoptera: Noctuiidae) and diamondback moth (Lepidoptera: Plutellidae). J. Econ. Entomol, Lanham, v. 90, n. 5, p. 1200-1206, 1997.

BAUR, M. E.; KAYA, H. K.; THURSTON, G. S. Factors affecting entomopathogenic nematode infection of Plutella xylostella on a leaf surface. Entomol. Exp. Appl., Oxford, v. 77, n. 3, p. 239-250, 1995.

CAMPOS, M. B. S.; MACEDO, N. Cana-de-açúcar ampliando campo de ataque. Cultivar: Grandes Culturas, Pelotas, v. 6, n. 68, p. 23-26, 2004.

CARVALHO, J. S. Aspectos reprodutivos de Diatraea saccharalis (Fabricius, 1794) (Lepidoptera: Crambidae) em condições de laboratório. 2006. Course Conclusion Work (Bachelor's in Biology) - Faculdade de Ciências Agrárias e Veterinárias. Universidade Estadual Paulista, Jaboticabal.

COMPANHIA NACIONAL DE ABASTECIMENTO - CONAB. Acompanhamento de safra brasileira: canade-açúcar, terceiro levantamento, janeiro/2011. Brasília: Companhia Nacional de Abastecimento, 2011.

DOLINSKI, C.; KAMITANI, F. L.; MACHADO, I. R.; WINTER, C. E. Molecular and morphological characterization of heterorhabditid entomopathogenic nematodes from the tropical rainforest in Brazil. Mem. Inst. Oswaldo Cruz, Rio de Janeiro, v. 103, n. 2, p. 150159, 2008.
DOLINSKI, C.; VALE, E. E. DEL; STUART, R. J. Virulence of entomopathogenic nematodes to larvae of the guava weevil, Conotrachelus psidii (Coleoptera: Curculionidae), in laboratory and greenhouse experiments. Biological Control, Meppel, v. 38, n. 3, p. 422-427, 2006.

FORST, S.; CLARKE, D. Bacteria-nematode symbiosis. In: GAUGLER, R. (Ed.). Entomopathogenic nematol. New York: CABI Publishing, 2002. p. 57-77.

GALLO, D.; NAKANO, O.; SILVEIRA NETO, S.; CARVALHO, R. P. L.; BAPTISTA, G. C. de; BERTI FILHO, E.; PARRA, J. R. P.; ZUCCHI, R. A.; ALVES, S. B.; VENDRAMIM, J. D.; MARCHINI, L. C.; LOPES, J. R. S.; OMOTO, C. Manual de entomologia agrícola. Piracicaba: Ceres, 1988. 649 p.

GALLO, D.; NAKANO, O.; SILVEIRA NETO, S.; CARVALHO, R. P. L.; BAPTISTA, G. C. de; BERTI FILHO, E.; PARRA, J. R. P.; ZUCCHI, R. A.; ALVES, S. B.; VENDRAMIM, J. D.; MARCHINI, L. C.; LOPES, J. R. S.; OMOTO, C. Entomologia agrícola. Piracicaba: Fealq, 2002. 920 p.

ISHIBASHI, N. Behaviour of entomopathogenic nematodes. In: LEE, D. L. (Ed.). The biology of nematodes. London: Taylor \& Francis, 2002. p. 511-520, 2002.

LEITE, L. G.; MACHADO, L. A.; AGUILLERA, M. M.; RODRIGUES, R. C. D.; NEGRISOLI JUNIOR, A. S. Patogenicidade de Steinernema e Heterorhabditis (Nematoda: Rhabditida) contra ninfas da cigarrinhadas-raízes da cana-de-açúcar, Mahanarva fimbriolata (Hemiptera: Cercopidae). Rev. Agric., São Paulo, v. 78, n. 1, p. 139-148, 2002.

LEITE, L. G.; TAVARES, F. M.; GINARTE, C. M. A.; CARREGARI, L. C.; BATISTA FILHO, A. Nematóides entomopatogênicos no controle de pragas. In: PINTO, A. S.; NAVA, D. E.; ROSSI, M. M.; MALERBO-SOUZA, D. T. (Org.). Controle biológico de pragas: na prática. Piracicaba: CP 2, 2006. p. 45-53.

LEWIS, E. E. Behavioural ecology. In: GAUGLER, R. Entomopathogenic nematology. New York: CABI Publishing, 2002. p. 205-223.

LIMA FILHO, M. Aperfeiçoamento dos sistemas de produção e liberação inundativa de Trichogramma galloi Zucchi (Hymenoptera: Trichogrammatidae) para o controle de Diatraea saccharalis (Fabricius) (Lepidoptera: Pyralidae) em cana-de-açúcar. 1999. Tese (Doutorado em Produção Animal) - Universidade Estadual do Norte Fluminense Darcy Ribeiro, Campos dos Goytacazes. 
MACEDO, N.; MACEDO, D. Manejo da broca protege produtividade. Correio Agrícola, São Paulo, v. 1, n. 1, p. 26-27, 2007.

MACHADO, L. A.; HABIB, M.; LEITE, L. G.; CALEGARI, L. C.; GOULART, R. M.; TAVARES, F. M. Patogenicidade de nematoides entomopatogênicos a ovos e larvas de Migdolus fryanus (Westwood, 1863) (Coleoptera: Vesperidae) Arq. Inst. Biol., São Paulo, v. 72, n. 2, p. 221-226, apr./june 2005.

MOZAMBANI, A. E.; PINTO, A. S.; SEGATO, S. V.; MATTIUZ, C. F. M. História e morfologia da cana-deaçúcar. In: SEGATO, S. V.; PINTO, A. S.; JENDIROBA, E.; NÓBREGA, J. C. M. Atualização em produção de cana-de-açúcar. Piracicaba: Prol Editora Gráfica, 2006. p. 11-18.

PEREZ, J.M.; MARTÍNEZ, E.; MACHADO, F.; PRADO, R.; RODRÍGUEZ, O.; MOLLINEDO, Y.; GONZÁLEZ, B. L. Utilización de nemátodos entomopatógenos en la lucha contra el cogollero del tabaco Centro Agrícola, Paraguai, n. 3, n. 27, july/sept. 2000.

PILLAY, U.; MARTIN, L. A.; RUTHERFORD, R. S.; BERRY, S. D. Entomopathogenic nematodes in sugarcane in south Africa. Proc. S. Afr. Sug. Technol. Ass., KwaZulu-Natal, v. 82, n. 1, p. 538-541, 2009.

PINTO, A. S.; GARCIA, J. F.; OLIVEIRA, H. N. Manejo das principais pragas da cana-de-açúcar. In: SEGATO, S. V.; PINTO, A. S.; JENDIROBA, E.; NÓBREGA, J. C. M. de. Atualização em produção de cana-de-açúcar. Piracicaba: Prol Editora Gráfica, 2006. p. 107-120.

SHAPIRO-ILAN, D. I.; GOUGE, D. H.; KOPPENHÖFER, A. M. Factors affecting commercial success: case studies in cotton, turf and citrus. In: GAUGLER, R. (Ed.). Entomopathogenic nematology. New Jersey: Rutgers University, 2002. p. 333-355.
SILVA, A. E. da; SILVA, A. N. da; VOSS, M. Compatibilidade de adjuvantes com o isolado EPNT 19 de nematoide entomopatogênico (Nematoda: Heterorhabditidae). In: MOSTRA DE INICIAÇÃO CIENTÍFICA DA EMBRAPA TRIGO, 4., 2008, Passo Fundo. Anais...Passo Fundo: [s.n.], 2008. Avaiable at: $</ /$ www.cnpt.embrapa.br/biblio/do/p_do94_10.htm>. Acessed at: 10 apr. 2012.

SMITH, K. A. Control of insect pests with entomopathogenic nematodes. 1994. Available at: $<$ http://www.fftc.agnet.org/library/article/tb139a.html.>. Acessed at: 13 anov. 2010.

SPAULL, V.W.Apreliminary evaluation of entomogenous nematodes to control the African sugarcane stalk borer Eldana Saccharina (Lepidoptera: Pyralidae). Proc S Afr Sug Technol Ass., KwaZulu-Natal, v. 62, n. 1, p. 120-123, 1988.

. Field tests to control the Pyralid, Eldana saccharina, with an entomogenou nematode, Heterorhabditis sp. Proc S Afr Sug Technol Ass., KwaZulu-Natal, v. 64, n. 1, p. 103-106, 1990.

TAVARES, F. M.; BATISTA FILHO, A.; LEITE, L. G.; ALMEIDA, L. C.; SILVA, A. C.; AMBRÓS, C. M. G. Efeito de Heterorhabditis indica e Steinernema sp. (Nemata: Rhabditida) sobre larvas do bicudo da cana-deaçúcar, Sphenophorus levis (Coleoptera: Curculionidae), em laboratório e casa-de-vegetação. Nematologia Brasileira, Piracicaba, v. 31, n. 1, p. 12-19, 2007.

WHITE, G. F. A method for obtaining infective nematode larvae from cultures. Science, Washington, v. 66, n. 1709, p. 302-303, 1927. 
